byl předsedou (2006-2012), našly by se ještě další časopisy, v jejichž redakčních radách působí nebo působil a jež dokládají uznání vědeckou komunitou. $V$ současnosti je na vrcholu tvůrčích sil, publikuje v periodikách registrovaných v prestižních databázích a připravuje další a další publikace a projekty v ČR i SR. Přejme mu další úspěchy, nové publikace a plodnou činnost ve prospěch mezinárodní slavistiky, komparatistiky a literární vědy.

Ivo Pospíšil

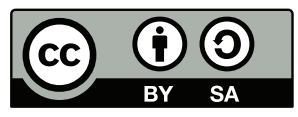

Toto dílo Ize užít v souladu s licenčními podmínkami Creative Commons BY-SA 4.0 International (<https:// creativecommons.org/licenses/by-sa/4.0/legalcode>). Uvedenése nevztahuje na díla či prvky (např. obrazovou či fotografickou dokumentaci), které jsou v díle užity na základě smluvní licence nebo výjimky či omezení príslušných práv.

https://doi.org/10.5817/OS2021-1-9

\title{
Strážce rodu Vančurů. K sedmdesátinám Jiřiho Poláčka
}

Roku 2020 si Jiří Poláček (narozen 13. března 1951 v Jablonném v Podještědí) vydal literárněhistorický bibelot s názvem Bratři Čapkové. Obsahuje sedm drobných př́spěvků o obou bratřích - ale nemylme se, Čapkové zdaleka nestáli a nestojí v popředí jeho zájmu. Ten byl vždycky namířen na jinou dvojici, ne sice bratrskou, ale rodovou na př́slušníky rodu Vančurů, na Antonína a Vladislava, z nichž první pojal pseudonym Jiří Mahen. Dědové obou těchto Vančurů byli bratřii a Vladislav Vančura oslovoval Mahena jako strýce.

Oběma tvůrcům věnoval Poláček pozornost už v sedmdesátých letech. O Vančurovi poprvé psal roku 1976 v Rovnosti (16. listopadu 1976), tehdy o jeho povídkách. O Mahenovi se poprvé vyjádřil o tři roky později, opět v Rovnosti (19. května 1979), stalo se tak $\mathrm{k}$ čtyřicátému výročí smrti čáslavského rodáka. $\mathrm{V}$ brněnské Rovnosti Poláček delší dobu redaktoroval.

O svém vztahu k Vančurovi se Poláček vyjádřil v rozhovoru s Jiří Rambouskem, uvedl tehdy: „Už jako studenta mě svým dílem i osobností uchvátil Vladislav Vančura. Věnoval jsem se dobovému kritickému ohlasu jeho próz - nejprve v diplomové práci a poté i v práci rigorózní. Také titul kandidáta věd jsem získal na základě vančurovské studie nazvané Postavy v próze Vladislava Vančury; v roce 1994 jsem ji vydal knižně pod názvem Portréty a osudy“ (Universitas 44, 2011, č. 1).

Poláček ve zmíněné monografii vystihuje především Vančurovy postavy. Při jejich líčení je přiléhavý, takto napřx. popisuje protagonistu jeho prvního románu: „Marhoulovo vnitřní ustrojení má v jádře konstantní podobu. Pod nárazy objektivní skutečnosti se mění jen zdánlivě nebo dočasně, podstatné změny doznává až v závěru 
románu. Teprve na prahu smrti se Jan ,sám zděsí svého nerozumu' a prohlédne (v této chvíli se také dovršuje polarizace jeho původně prostého, nediferencovaného poměru $\mathrm{k}$ lidem). Takovéto quijotovské prohlédnutí in articulo mortis se $\mathrm{v}$ české literatuře dvacátých let vyskytovalo poměrně často, ale většinou mělo mystické zabarvení."

Na jiném místě se Poláček upíná na nomina propria Vančurových figur. Zjištuje, že ve třech povídkách Amazonského proudu se vyskytuje jméno Jan a dodává $\mathrm{k}$ tomu: „Je to jméno běžné. Vančura ho však měl ve velké oblibě a často s ním ve své tvorbě pracoval. Jeho Janové se od sebe samozřejmě v lecčems liší, ale zároveň v mnohém shodují; jejich jméno má znakovou povahu, signalizuje vnitřní ustrojení svého nositele, charakteristické mimo jiné značnou snivostí. Obdobnou řadu ve Vančurově díle tvoří Josefíny."

Portréty a osudy jsou cele věnovány Vančurovi, v druhé Poláčkově publikaci, Tvorba a recepce, prodlužuje svůj zájem o jeho dílo o dalších pět studií, převážně ohlasového rázu.

K Jiřímu Mahenovi přistupuje Poláček poněkud jinak. Zejména jako předseda Společnosti Jiřího Mahena a jako redaktor jejího zpravodaje nesoucího název Milír. V něm také uveřejnil několik mahenovských př́spěvků. Některé z nich mají kuriózní pozadí. Tak např. ve stati Mahenova sbírka Duha a její soudobá recepce (Milír 18, 2016) píše o frekvenci čísla sedm v této básníkově válečné knize. Vyvstává zde tak souvislost s Poláčkovým bibelotem Bratři Čapkové, kam také on zařadil statě stejného počtu. Je i v této své publikaci (bezděčně či záměrně) mahenovský.

Vedle své odborné práce je Jiří Poláček rovněž esejista, což plně projevil ve svém Básnickém roku, v němž vysledoval, jak čeští básníci pojímali a charakterizovali jednotlivé měsíce roku. Autor Plamínků je v něm zastoupen několikrát. Tak napr. v květnové pasáži se o daném měsíci praví: „Jiné ladění má Májový večer Jiřího Mahena: působí pohádkově, leč ,pohádka se někde ztrácí a zbylo jen zklamání'“" V následujícím červnovém oddíle se k Mahenovi vrací: „Jiří Mahen v básni Červen tento měsíc nazval ,měsícem síly', která ,zemí probila se všech barev přivalem, a nyní slávou kypí, hřmí a duní v zmužnělém srdci tvém،““

Pro Poláčka je posléze př́značné, že když si roku 2013 vydal svoji bibliografii, dal si na její obálku Ladův portrét autora Chrousta.

O vzájemném vztahu Mahena a Vančury Poláček promluvil na mahenovské konferenci, konané $\mathrm{v}$ prosinci 1982. Následujícího roku vyšel jeho prŕíspěvek v konferenčním sborníku nazvaném Jiří Mahen, spolutvưrce pokrokové kulturní politiky. Jeho stat’ se příznačně jmenuje Jiří Mahen a Vladislav Vančura. Vše, co je v ní řečeno, se opírá o dokladový materiál.

Poláček je nejen upnut k oběma Vančurům, ale on sám ve své odborné práci shledává a nachází jevy podvojné - jeho první knižní práce se příznačně jmenuje Portréty a osudy a druhá Tvorba a recepce. 
Sepětí mezi Vančurou a Mahenem se projevilo i v oblasti dedikací - Vančura připsal Markétu Lazarovou Mahenovi a Mahen mu věnoval Požár Tater. Jiřímu Poláčkovi budiž dodán alespoň tento neumělý rispet:

Fiři stojí za milírem, sleduje portréty a osudy, ovívá se modrým vějírem, prost jakékoliv ostudy.

Uběhl nový básnický rok, $v$ němž učiněn další krok $k$ tvorbě a recepci $v$ mahenovském kotci.

František Všetička

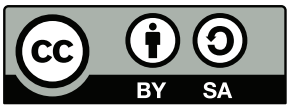

Toto dílo Ize užít v souladu s licenčními podmínkami Creative Commons BY-SA 4.0 International (<https:// creativecommons.org/licenses/by-sa/4.0/legalcode>). Uvedené se nevztahuje na díla či prvky (např. obrazovou či fotografickou dokumentaci), které jsou v díle užity na základě smluvní licence nebo výjimky či omezení př́slušných práv.

\section{https://doi.org/10.5817/OS2021-1-10}

\section{Odešel prof. PhDr. Miroslav Zahrádka, DrSc.}

25. května, kratičce po svých 90. narozeninách, ukončil své životní putování rusista, literární vědec, literární a divadelní kritik, publicista, překladatel a spisovatel prof. PhDr. Miroslav Zahrádka, DrSc., dlouholetý vedoucí rusistického a slavistického pracoviště na Filozofické fakultě Univerzity Palackého v Olomouci.

Profesor Zahrádka se narodil 14. května 1931 v Kralupech nad Vltavou. Tam absolvoval školní docházku včetně gymnaziální, po ní následovalo studium ruštiny a češtiny na Filozofické fakultě Univerzity Karlovy v Praze. Krátké působení na Vysoké škole ruského jazyka a literatury tamtéž bylo vystřídáno aspiranturou v Moskvě, která se stala dobou poznávání reálného stavu společnosti v Sovětském svazu a navazování prátelství s mnoha osobnostmi ruské literatury i literární vědy. Od roku 1960 pak bylo a je jméno Miroslava Zahrádky spjato s Olomoucí a olomouckou rusistikou, kterým zůstal věrný až do svého odchodu do důchodu, po němž podle toho, jak mu dovolovaly síly, pořád ještě pracoval. 